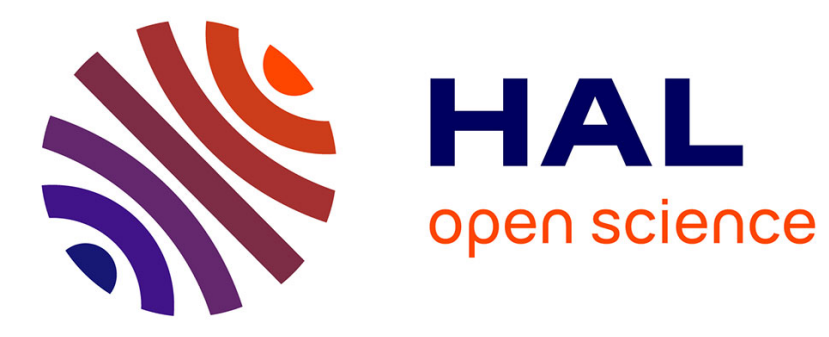

\title{
Influence of steroid hormones on ventricular repolarization
}

Joe-Elie Salem, Joachim Alexandre, Anne Bachelot, Christian Funck-Brentano

\section{To cite this version:}

Joe-Elie Salem, Joachim Alexandre, Anne Bachelot, Christian Funck-Brentano. Influence of steroid hormones on ventricular repolarization. Pharmacology and Therapeutics, 2016, 167, pp.38 - 47. 10.1016/j.pharmthera.2016.07.005 . hal-01393416

\section{HAL Id: hal-01393416 https://hal.sorbonne-universite.fr/hal-01393416}

Submitted on 7 Nov 2016

HAL is a multi-disciplinary open access archive for the deposit and dissemination of scientific research documents, whether they are published or not. The documents may come from teaching and research institutions in France or abroad, or from public or private research centers.
L'archive ouverte pluridisciplinaire HAL, est destinée au dépôt et à la diffusion de documents scientifiques de niveau recherche, publiés ou non, émanant des établissements d'enseignement et de recherche français ou étrangers, des laboratoires publics ou privés. 


\title{
Influence of Steroid Hormones on Ventricular Repolarization
}

\author{
Joe-Elie Salem, M.D.*; Joachim Alexandre, M.D., Ph.D.**,
}

Anne Bachelot, M.D., Ph.D. \#, Christian Funck-Brentano, M.D., Ph.D.*

* INSERM, CIC-1421 and UMR ICAN 1166; AP-HP, Pitié-Salpêtrière Hospital, Department of Pharmacology and CIC-1421; Sorbonne Universités, UPMC Univ Paris 06, Faculty of Medicine; Institute of Cardiometabolism and Nutrition (ICAN), F-75013 Paris, France.

** Normandie Université, France; EA 4650, Signalisation, électrophysiologie et imagerie des lésions d'ischémie-reperfusion myocardique; Pharmacology department, CHU Caen, F-14032 Caen, France.

\# AP-HP, Pitié-Salpêtrière Hospital, IE3M, Department of Endocrinology and Reproductive Medicine, and Centre de Référence des Maladies Endocriniennes Rares de la croissance et Centre des Pathologies gynécologiques Rares, and CIC-1421, F-75013 Paris, France

Corresponding author: Christian Funck-Brentano, christian.funck-brentano@aphp.fr, Centre d'Investigation Clinique Paris-Est, Hôpital La Pitié-Salpêtrière, 47-83 Bld de l'hôpital, 75651 Paris Cedex 13, Secretariat : +331421785 31, Fax : +33142178532 
Abstract (243 words)

QT interval prolongation, corrected for heart rate (QTC), either spontaneous or drug-induced, is associated with an increased risk of torsades de pointes and sudden death. Women have longer QTC than men and are at higher risk of torsades de pointes, particularly during post-partum and the follicular phase. Men with peripheral hypogonadism have longer QTc than healthy controls. The role of the main sex steroid hormones has been extensively studied with inconsistent findings. Overall, estradiol is considered to promote QTc lengthening while progesterone and testosterone shorten QTc. New findings suggest more complex regulation of QTc by sex steroid hormones involving gonadotropins (i.e. follicle-stimulating hormone), the relative concentrations of sex steroid hormones (which depends on gender, i.e., progesterone/estradiol ratio in women). Aldosterone, another structurally related steroid hormone, can also prolong ventricular repolarization in both sex. Better understanding of pathophysiological hormonal processes which may lead to increased susceptibility of women (and possibly hypogonadic men) to drug-induced arrhythmia may foster preventive treatments (e.g. progesterone in women). Exogenous hormonal intake might offer new therapeutic opportunities or, alternatively, increase the risk of torsades de pointes. Some exogenous sex steroids may also have paradoxical effects on ventricular repolarization. Lastly, variations of QTc in women linked to the menstrual cycle and sex hormone fluctuations are generally ignored in regulatory thorough QT studies. Investigators and regulatory agencies promoting inclusion of women in thorough QT studies should be aware of this source of variability especially when studying drugs over several days of administration.

Key words: Gonadal Steroid Hormones, Gonadotropins, Aldosterone, Mineralocorticoid Receptor Antagonists, QTc, Long QT Syndrome.

Abbreviations: FSH, Follicle-stimulating Hormone; LQTS, Long QT Syndrome 


\section{Contents}

1. Introduction

2. Impact of the main sex steroid hormones on QTc: estradiol, testosterone, progesterone 5

3. Complex interactions between gonadotropins and steroid sex hormones on QTc interval 10

4. Direct vs. indirect effects of sex hormones on cardiac ionic current.

5. Impact of aldosterone, a non-sex steroid hormone, on cardiac repolarization 12

6. Perspectives for a better understanding of processes linking sex hormones and QTC 14

7. Exogenous hormone intake: new therapeutic perspectives or source of proarrhythmic risk? 14

8. Implications for inclusion of women in thorough QT studies. 16

9. Conclusion 16

Conflict of interest statement 17

References. 18 


\section{Introduction}

The QT interval of the electrocardiogram (ECG), corrected for heart rate (QTc), is a measure of the duration of ventricular repolarization and is a widely used surrogate marker of ventricular arrhythmia risk (Curtis, M.J., et al., 2013; Pugsley, M.K., et al., 2008). It remains the gold standard in human studies despite its well-recognized limitations (Curtis, M.J., et al., 2013; Pugsley, M.K., et al., 2008). Bazett's correction $\left(\mathrm{QTcB}=\mathrm{QT} / \mathrm{RR}^{\wedge 0.5}\right)$ has been widely used but Fridericia's correction $\left(\mathrm{QTcF}=\mathrm{QT} / \mathrm{RR}^{\wedge 0.33}\right)$ is currently preferred in accordance with the E14 ICH Guideline adopted by FDA and EMA in 2005. This latter correction is more accurate than Bazett's (Funck-Brentano, C. \& Jaillon, P., 1993).

In the healthy population, from puberty to menopause, QTc is longer in women than in men. This gender difference in normal QTc values decreases with age due to progressive QTc lengthening in males until it reaches the level of women around the age of female menopause (Mason, J.W., et al., 2007; Rautaharju, P.M., et al., 2014; Vicente, J., et al., 2014). Therefore age- and sex-specific criteria could influence the definitions of upper normal limits for evaluation of QTc prolongation and increased arrhythmic burden (Mason, J.W., et al., 2007; Rautaharju, P.M., et al., 2014). Although risk scores have been developed (Tisdale, J.E., et al., 2013), there is no gender-specific threshold of QTc prolongation at which torsade de pointes is certain to occur. A QTc $>500 \mathrm{~ms}$, and to a greater extent a QTc > $550 \mathrm{msec}$, are associated with at least a 2 to 3 fold increased risk of torsade (Priori, S.G., et al., 2003; Sauer, A.J., et al., 2007). Locati et al. reported gender-related differences in cardiac events in long QT syndrome (LQTS) carriers (Locati, E.H., et al., 1998). This gender related difference was age-dependent. In LQTS patients, the risk of cardiac events is considered higher in males until puberty and higher in females during adulthood (Locati, E.H., et al., 1998; Priori, S.G., et al., 2003; Sauer, A.J., et al., 2007). Modulation of ventricular ion-channels by sex hormones has been emphasized (Coker, S.J., 2008).

In the general adult population, female gender is associated with a higher risk of torsades de pointes. This arrhythmia occurs twice as often in women as it does in men (Coker, S.J., 2008; Makkar, R.R., et al., 1993; Roden, D.M., 2004; Yap, Y.G. \& Camm, A.J., 2003). Women of childbearing age are at 
greater risk of QT prolongation during the follicular phase (Burke, J.H., et al., 1997; Endres, S., et al., 2004; Nakagawa, M., et al., 2006). LQTS carriers have a reduced risk for cardiac events during pregnancy, but an increased risk during the 9-month postpartum period, especially among women with the LQT2 genotype (Seth, R., et al., 2007). It was however not specified if these cardiac events were torsades de pointes related to QT prolongation or other arrhythmias unrelated to QT prolongation. Anneken et al. recently reported that QTc was shortened during pregnancy in patients with LQTS type 2 as compared to the post-partum period (Anneken, L., et al., 2016). The effect of sex steroid hormones on cardiac repolarization, mainly estradiol, progesterone and testosterone, has been suspected for many years but is still a matter of debate. Conflicting results have been obtained, possibly amplified by use of variable methods of QT correction for heart rate. Aldosterone also appears to influence ventricular repolarization (Matsumura, K., et al., 2005; Maule, S., et al., 2006). The electrophysiological and molecular differences in male and female cardiac electrophysiology have been discussed earlier (Jonsson, M.K., et al., 2010; Yang, P.C. \& Clancy, C.E., 2010). Here, we review the current knowledge about the influence of sex hormones and aldosterone on QTc interval with particular emphasis on clinical studies and potential clinical and regulatory implications.

\section{Impact of the main sex steroid hormones on QTc: estradiol, testosterone, progesterone}

\section{- In women: estradiol and progesterone have opposite effects on QTc interval [Table 1-2]}

The end of the follicular phase is characterized by high estradiol and low progesterone levels while the luteal phase is characterized by high progesterone with lower estradiol levels and menses (first part of the follicular phase) by both low progesterone and estradiol levels (Chabbert Buffet, N., et al., 1998; Mahesh, V.B., 1985) (Figure 1). Burke et al. showed in 20 women under double autonomic blockade (atropine-propranolol) that QTc interval was shorter $(p \leq 0.05)$ during the luteal phase ( $438 \pm 16 \mathrm{~ms})$ than during the menstrual $(446 \pm 15 \mathrm{~ms})$ or the follicular phase $(444 \pm 13 \mathrm{~ms})$ (Burke, J.H., et al., 1997). Endres et al. confirmed these results in 22 women also exposed to double autonomic blockade (Endres, S., et al., 2004) and Nakagawa et al. showed that, compared to men, QTc was longer 
in women only during the follicular phase (Nakagawa, M., et al., 2006). To assess if the luteal phase was protective against drug-induced QTc lengthening, a prospective interventional study including 58 healthy adults was conducted (Rodriguez, I., et al., 2001). Twenty two men and 38 men were administered ibutilide, a drug with class III antiarrhythmic properties due to activation of a slow inward sodium current and inhibition of the delayed rectifier potassium channel (IKr). Cumulative QTc increase over time with ibutilide infusion, was compared using area under the curve of the change in QTc versus time over 60 minutes from the onset of infusion. Women received the drug on 3 different occasions: menstrual, ovulatory follicular and luteal phases. Ibutilide-induced QTC prolongation was greater $(p<0.01)$ in women during menses $(63 \pm 13 \mathrm{~ms})$ and the ovulatory phase $(59 \pm 17 \mathrm{msec})$ than during the luteal phase $(53 \pm 14)$ and in men $(46 \pm 16 \mathrm{~ms})$. Drug-induced QTc prolongation negatively correlated with plasma progesterone and the progesterone/estradiol ratio $(r=-0.4)$ but did not correlate with estradiol or testosterone levels (Rodriguez, I., et al., 2001). Of note, except for one study which analyzed log estradiol ( $r=-0.43$ ) (Nowinski, K., et al., 2002), no correlation was found between estradiol levels and QTc (Hulot, J.S., et al., 2003; Zhang, Y., et al., 2011). Therefore, most studies found a protective effect of the luteal phase, characterized by high progesterone exposure, on drug-induced QTc prolongation (Figure 1). However, it should be emphasized that the extent to which these variations of QTc interval duration observed during menstrual cycle, either spontaneously or drug-induced, are associated to changes in the risk of torsades de pointes remains unknown.

In women, menopause or bilateral oophorectomy is associated with a fall of estradiol and progesterone levels which, if too symptomatic, may require hormone replacement therapy. Several studies examined the effect of estrogen with or without progestin supplementation on the QTC interval. The type of progestin used was rarely reported. Some studies found that administration of estradiol alone was associated with QTc increase while QTc did not change in patients under combined progestin-estrogen due to a progestin counterbalancing effect (Carnethon, M.R., et al., 2003; De Leo, V., et al., 2000; Haseroth, K., et al., 2000; Kadish, A.H., et al., 2004; Lee, T.M., et al., 1999). This finding was not confirmed in other studies but the type of progestins and estrogens used were not specified 
precluding further understanding of these conflicting results (Larsen, J.A., et al., 1998; Nowinski, K., et al., 2002). Thus, it cannot be concluded that all progestins shorten QTc interval since pharmacological properties differ among the various progestins used in menopause. Besides progesterone, the natural progestin, there are several derived compounds, whose spectrum of actions and interaction varies depending on the type of steroid hormone receptor considered. Therefore, different biological effects of synthetic progestins may be exerted at the end organ or tissue levels (Sitruk-Ware, R., 2008).

Sex steroid hormones exert non-genomic actions on cardiac repolarization (Kurokawa, J. \& Furukawa, T., 2013). In guinea pig ventricular myocytes, acute applications of physiological serum levels of progesterone suppress a depolarizing current, ICaL, and enhance a repolarizing current, IKs (Figure $2 \mathrm{~A}$ ), resulting in shortening of the duration of ventricular action potentials (Nakamura, $\mathrm{H}_{\text {., }}$ et al., 2007). In female rabbit hearts, progesterone protects against prolongation of action potential duration and triangulation induced by the inhibition of a number of potassium channels by quinidine, including IKr, IK1, and Ito (Tisdale, J.E., et al., 2011). Moreover, in prepubertal ovariectomized transgenic LQT2 rabbits, progesterone significantly shortened QTc interval by decreasing ICaL density (Odening, K.E., et al., 2012). Using patch-clamp recordings, guinea pig hearts and cultured cells overexpressing $\mathrm{IKr}$, physiological concentrations of $17 \beta$-oestradiol induced modifications of voltagedependence that partially suppressed IKr in a receptor-independent manner (Kurokawa, J., et al., 2008). Using patch-clamped recordings from ventricular myocytes isolated from female rabbits, $17 \beta-$ estradiol upregulated the cardiac sodium-calcium exchanger and induced early afterdepolarizations by a genomic mechanism mediated by estrogen receptors, and de novo mRNA and protein biosynthesis (Chen, G., et al., 2011). In these experiments, the subsequent addition of dofetilide to the bathing solution prolonged action potential durations but only myocytes treated with $17 \beta$-estradiol exhibited early afterdepolarizations ( $n=6$ out of 6 cells). The subsequent addition of KB-R7943, an inhibitor of the sodium-calcium exchanger, to the bathing solution reduced action potential durations in all cells and suppressed early afterdepolarizations in all cells incubated with $17 \beta$-estradiol. Therefore, the authors concluded that in female hearts, $17 \beta$-estradiol could contribute to the enhanced propensity 
to early afterdepolarization, the substrate of torsade de pointes, in female hearts (Chen, G., et al., 2011). A proarrhythmic effect of acute administration of $17 \beta$-estradiol, independent of gender, was shown in an $\alpha(1)$-adrenoceptor-stimulated anaesthetized rabbit model receiving the $\mathrm{IKr}$ blocker clofilium (Philp, K.L., et al., 2007).

\section{- In women: pathological elevations in testosterone shorten QTc [Table 2]}

Testosterone levels are very low in women vs men, except in some pathological hormonal conditions where women are androgenized. Testosterone levels found in healthy women of childbearing age (Nakagawa, M., et al., 2006) or post-menopausal women (Zhang, Y., et al., 2011) do not correlate with baseline QTc (Rodriguez, I., et al., 2001). In contrast, congenital adrenal hyperplasia and polycystic ovary syndrome patients presenting with higher levels of testosterone have shorter QTC intervals than normal healthy women. In these latter conditions with high variability of testosterone levels in women, a negative correlation $(r=-0.2$ to -0.5$)$ was found between testosterone levels and QTc (Abehsira, G., et al., 2016; Gazi, E., et al., 2013; Vrtovec, B., et al., 2001).

\section{- In men: normal levels of testosterone shorten QTc [Table 3]}

Bidoggia et al. first showed that QTC was longer in castrated men when compared to virilized women or healthy men (Bidoggia, H., et al., 2000), the latter presenting with similar QTc (Abehsira, G., et al., 2016; Gazi, E., et al., 2013; Vrtovec, B., et al., 2008). This suggests a shortening effect of testosterone on QTc in normal healthy men. Several cross-sectional studies involving thousands of men with variable age and levels of testosterone (445 in a Rotterdam cohort, 1428 in the study of health in Pomerania, 727 in the Third National Health and Nutrition Examination Survey and 2942 in the Multi-Ethnic Study of Atherosclerosis) (van Noord, C., et al., 2010; Zhang, Y., et al., 2011) confirmed the potential shortening effect of testosterone on QTc in men. After multivariable analysis, men in the highest tertile or quartile of testosterone levels had significantly shorter QTc than those in the lowest subgroups. QTc shortening was more strongly associated with the free testosterone fraction than with

total testosterone levels. A prospective interventional study (Charbit, B., et al., 2009) conducted in 11 
hypogonadic men assessed at different times after their last testosterone administration showed that QT at 60 bpm, i.e. QTc, was shorter (352ms IQ[340-363]; $\mathrm{p}<0.013)$ at higher total testosterone concentrations $(52.6 \mathrm{nmol} / \mathrm{L})$, intermediate $(357 \mathrm{~ms} \mathrm{IQ}[349-367])$ at medium concentrations $(35.8 \mathrm{nmol} / \mathrm{L})$ and longer (363ms IQ[357-384]) at lowest testosterone concentration (6nmol/L). In patients with Klinefelter syndrome, characterized by elevated gonadotropin and low testosterone levels, QTc was shorter in patients treated with testosterone than in untreated patients (Jorgensen, I.N., et al., 2015). In contrast, when administered to elderly patients and patients with heart disease with only slight androgen deficit and numerous comorbidities potentially altering QTc duration, acute or chronic administration of testosterone reaching physiological or supra-physiological concentrations was not associated with QTc change (Malkin, C.J., et al., 2003; White, C.M., et al., 1999). Of note, no study has reported significant associations between endogenous estradiol or progesterone levels and QTc in men (Pecori Giraldi, F., et al., 2011; Zhang, Y., et al., 2011), even in patients with congenital adrenal hyperplasia who express high progesterone levels (Abehsira, G., et al., 2016). Coker reviewed animal models supporting the difference in ventricular repolarization duration due to sex hormones (Coker, S.J., 2008). Also, estradiol has been reported to be $\sim 10$ fold more potent in blocking ICaL and reducing ischemia-induced arrhythmias in female rats than in male rats (Philp, K.L., et al., 2006).

Experimental data are in line with the clinical findings that testosterone shortens QTc in men. Indeed, in rabbit right ventricular strip preparations superfused with Tyrode's solution, testosterone decreased action potential duration (Alexandre, J., et al., 2015). In Langendorff-perfused guinea-pig hearts, acute administration of testosterone shortened action potential duration (Figure 2C) (Bai, C.X., et al., 2005). In whole-cell patch-clamp recordings, an increase in IKr amplitude ( 13-15\%) was also reported with physiological acute administration of testosterone in a neuroblastoma cell line overexpressing this current (Ridley, J.M., et al., 2008). Since IKr enhancement was rapid following acute administration of testosterone, it was felt unlikely that this effect could have been mediated through a genomic effect. However, the increase in $\mathrm{IKr}$ amplitude was inhibited by the androgen receptor antagonist flutamide suggesting a "classical" genomic pathway via activation of androgen receptors. 
In addition, testosterone also increases IKs in guinea-pig ventricular preparations (Bai, C.X., et al., 2005) and modestly decreases ICaL in both vascular and cardiac L-type Ca2+ channels under physiological conditions (Scragg, J.L., et al., 2004; Wagner, M., et al., 2011). These findings were also reported in humans where it was suggested that the effects of testosterone on ICaL played a greater role than its effects on IKs in shortening early repolarization (Vicente, J., et al., 2014).

\section{Complex interactions between gonadotropins and steroid sex hormones on QTc interval}

Recently, we showed that QTc interval is influenced by complex interactions between sex steroid hormones and gonadotropins depending on gender (Table 4), rather than on one single hormone (Abehsira, G., et al., 2016). Progesterone/estradiol ratio in women, testosterone in men and FSH in both genders were major determinants of the duration of ventricular repolarization. FSH was positively correlated to QTc ( $r=0.39$ and $r=0.38$, respectively in men and women) while free testosterone in men $(r=-0.34)$ and progesterone/estradiol ratio in women $(r=-0.38)$ were negatively correlated. This finding is supported by the fact that FSH receptors are present in the myocardium (GeneCards). In women, FSH ovulary peak during the follicular phase might contribute to their higher sensitivity to drug-induced QTc lengthening at this peculiar moment (Rodriguez, I., et al., 2001). In men with hypogonadism, QTc was longer compared to healthy men (Bidoggia, H., et al., 2000; Charbit, B., et al., 2009) except in those with hypogonadotropic hypogonadism (Kirilmaz, A., et al., 2003). In those latter patients, low FSH $(0.6 \pm 0.9 \mathrm{mlU} / \mathrm{ml})$, not promoting QTc lengthening $(403 \pm 36$ vs $408 \pm 25 \mathrm{msec}$, in hypogonadotropic vs healthy men, respectively, p-value not significant), despite low total testosterone levels ( $71 \pm 92 \mathrm{ng} / \mathrm{dL})$ might explain this observation (Kirilmaz, A., et al., 2003). Furthermore, complete androgen blockade with bilateral orchiectomy plus peripheral anti-androgen therapy (surgical group) was associated with a faster and more important QTc lengthening in 65 patients with prostate cancer than central blockade of gonadotrophins release (i.e decrease in FSH release) plus peripheral anti-androgen medication (medical group) (Sağlam, H., et al., 2012). Pre-treatment QTc changed from $412 \pm 27$ to $422 \pm 40 \mathrm{msec}$ 
(ns) and from $422 \pm 29 \mathrm{msec}$ to $440 \pm 34 \mathrm{msec}(\mathrm{p}=0.007)$ at three months in the medical and surgical groups, respectively (Sağlam, H., et al., 2012).

\section{Direct vs. indirect effects of sex hormones on cardiac ionic current.}

The mechanisms of hormones influences on repolarization are complex, combining genomic and nongenomic pathways. The precise mechanisms of action of hormones on ventricular repolarization is still unresolved. This may be due to different experimental conditions using variable models, hormone doses or combinations. Studies found only moderate correlations between individual sex hormones and QTc (Abehsira, G., et al., 2016). Several groups raised the question of whether the effect of sex hormones on ion channels and cardiac repolarization involved genomic or nongenomic pathways. Non-clinical studies indicated that sex steroid hormones may lead to a transcriptional, posttranscriptional or post-translational effect on ion channels expression and regulation more than a direct channel on/off effect but quantitative comparison are lacking (Anneken, L., et al., 2016; Boyle, M.B., et al., 1987; Drici, M.D., et al., 1996; Liu, X.K., et al., 2003). Steroid hormones affect transcriptional processes, involving nuclear translocation, and bind to specific response elements, ultimately leading to regulation of gene expression (Evans, R.M., 1988). The actions of steroid hormones on ion channels opening and action potential duration are too rapid to be mediated by RNA and protein synthesis and are considered to be primarily related to non-genomic signaling mechanisms directly influencing ion currents (Alexandre, J., et al., 2014; Pham, T.V., et al., 2001). It was reported that physiological levels of steroid hormones could acutely modify cardiac repolarization by regulating cardiac ion channels via non-genomic pathways including nitric oxide (NO) released from NO synthase 3 (Bai, C.X., et al., 2005; Pham, T.V., et al., 2001). Testosterone acutely affects cardiac repolarization by modulating IKs and $\mathrm{ICa}, \mathrm{L}$ through nongenomic pathways including the androgen receptor, Akt and the NO synthase 3 (Bai, C.X., et al., 2005). Progesterone modulates cardiac repolarization and rapidly shortens action potential duration. This was attributed mainly to IKs enhancement and inhibition of ICaL through a nongenomic pathway involving c-Src/PI3K/Akt- dependent eNOS activation (Nakamura, H., et al., 2007). Elevated 
estradiol levels were associated with shorter QTc intervals in healthy women and female LQT-2 patients via enhanced estradiol-receptor-a-mediated Hsp90 interaction, increased membrane trafficking and thereby increased K+ repolarizing currents (Anneken, L., et al., 2016).

Animal models, have provided important electrophysiological information on the actions of steroid hormones (Alexandre, J., et al., 2013; Franz, M.R., et al., 1992; Lawrence, C.L., et al., 2005; Thomsen, M.B., et al., 2006; Yan, G.X., et al., 1998). Steroid hormones are involved in complex regulatory pathways in various tissue and organs, meaning that if their effects on cardiac myocytes are in any way dependent on noncardiac actions, these will not be detected in studies using isolated myocytes.

\section{Impact of aldosterone, a non-sex steroid hormone, on cardiac repolarization}

It is now well established that, compared to patients with essential hypertension, QTc interval is prolonged in patients with hyperaldosteronism (primary aldosteronism or Conn's adenoma), with a high proportion of patients experiencing QTc values higher than 440 ms (Matsumura, K., et al., 2005; Maule, S., et al., 2011). Several explanations may be proposed. First, the presence of higher blood pressure levels, due to the increased aldosterone secretion, might contribute to QT interval prolongation in these patients (Maule, S., et al., 2011). Indeed, hyperaldosteronism is associated with high blood pressure levels and left ventricular hypertrophy (Milliez, P., et al., 2005) and patients with left ventricular hypertrophy exhibit prolonged QT interval (Dritsas, A., et al., 1992; Martin, A.B., et al., 1994) possibly as a consequence of down-regulation of the human ether-a-go-go related gene expression (Hu, C., et al., 2011). Secondly, in case of hyperaldosteronism, patients usually exhibit a depletion of intracellular potassium concentration. Potassium is the most abundant intracellular cation. The electrophysiological effects of potassium depend not only on its intra and extracellular concentration, but also on the direction (hypokalemia vs hyperkalemia) and rate of change (Hoffman, B.F. \& Suckling, E.E., 1956) that directly modulates potassium currents (Ishihara, K., et al., 1989) and ventricular repolarization. Indeed, $\mathrm{IKr}$ activation depends on potassium concentration and this 
concentration modulates QT interval duration (Yang, T. \& Roden, D.M., 1996). In human, it was demonstrated that an oral potassium supplementation can safely increase serum potassium and correct QTc interval and QT dispersion in LQT-2 subjects (Etheridge, S.P., et al., 2003). Finally, aldosterone could also modify cardiac repolarization, via both genomic and non-genomic modulation of ionic currents expression and activity (Figure 2D). In a transgenic mouse model with conditional cardiac-specific overexpression of the human mineralocorticoid receptor, cardiac repolarization was prolonged due to a downregulation of Ito and an increase in ICaL (Benitah, J.P. \& Vassort, G., 1999; Ouvrard-Pascaud, A., et al., 2005). In adult guinea pigs aldosterone administration for 28 days via osmotic pumps prolonged QT interval and action potential duration. This was attributed to a decrease in IKs density associated with a reduction in the mRNA/protein expression of IKs channel pore and auxiliary subunits, KCNQ1 and KCNE1 (Lv, Y., et al., 2015). Aldosterone also modulates cardiac repolarization via non-genomic pathway. Indeed, acute intravenous administration of aldosterone in patients with supraventricular arrhythmias increased monophasic action potential duration within minutes (Tillmann, H.C., et al., 2002). This might be explained by IKr and IKs decrease by aldosterone, an effect not attributable to the mineralocorticoid receptor (Caballero, R., et al., 2003).

These observations have been confirmed by pharmacological manipulations using mineralocorticoid receptor antagonists. Spironolactone, a nonselective mineralocorticoid receptor antagonist, in contrast with its blocking properties on human IKr (Caballero, R., et al., 2003), shortened QTc in primary aldosteronism (from $423 \pm 23$ ms to $403 \pm 12 \mathrm{~ms}$; $\mathrm{P}<0.01$ ) (Maule, S., et al., 2011) and in coronary artery disease patients without heart failure (from $440 \pm 28 \mathrm{~ms}$ to $425 \pm 25 \mathrm{~ms} ; \mathrm{P}<0.001$ ) (Shah, N.C., et al., 2007). Spironolactone also reduced QTc dispersion and shortened QTc in patients with systolic heart failure (Yee, K.M., et al., 2001). These clinical findings are in line with experimental data showing that spironolactone fully prevented aldosterone-induced electrophysiological changes (prolongation of QT interval and action potential duration) by restoration of IKs density (Lv, Y., et al., 2015). Moreover, the administration of eplerenone, a selective aldosterone antagonist, during 5 weeks 
successfully prevented the prolongation of ventricular repolarization and refractoriness induced by aldosterone in a rapid ventricular pacing-induced heart failure model (Stambler, B.S., et al., 2009).

\section{Perspectives for a better understanding of processes linking sex hormones and QTC}

The lengthening effect of FSH on QTc is a recent finding (Abehsira, G., et al., 2016). Polycystic ovary syndrome patients may require recombinant FSH administration to improve their fertility (Norman, R.J., et al., 2007). It would be worth evaluating if the short QTc found in this disease is corrected by FSH administration (Vrtovec, B., et al., 2008).

Sex steroid hormone and FSH receptors also exhibit polymorphisms or mutations leading to either a hyperactive or inactive state (Lussiana, C., et al., 2008). Exploring the influences of these polymorphisms on QTc interval deserves specific investigations. Patients included in large population GWAS studies evaluating polymorphisms linked to QTc interval duration (Arking, D.E., et al., 2014) found an insignificant association with a single nucleotide polymorphism related to FSHR $\left(p=3 * 10^{-3}\right)$. The only study evaluating polymorphisms linked to drug-induced torsades de pointes was negative for any single nucleotide polymorphism (Behr, E.R., et al., 2013). Subjects included in these studies had multiple confounding factors for QTc assessment such as uncontrolled levels of electrolytes (e.g. dyskalemia), heart diseases with variable activation of the renin-angiotensin-aldosterone system or intake of drugs prolonging QTc including steroid modulators. Furthermore, their hormonal status was highly heterogeneous with the inclusion of children, men, menopausal women and women of childbearing age studied during menses, luteal and ovulatory phases. A hormone receptor polymorphism is unlikely to have the same influence on QTc in an adult and in a child, in a man and in a women or at different times of the menstrual cycle.

\section{Exogenous hormone intake: new therapeutic perspectives or source of proarrhythmic risk?}

Humans can be exposed to several situations where an exogenous hormonal intake is required. Except for substitutive treatment in post-menopausal women, very few studies focused on the effect 
of such pharmacological interventions on QTc in clinical practice. Alizade et al. showed in 33 competitive male bodybuilders, 15 of whom had been actively using androgenic anabolic steroids for more than 2 years and 18 who had never used them, that QTC was longer in men using androgenic anabolic steroids (oxymetholone, stanozolol, nandrolone, testosterone propionate) compared to control subjects (Alizade, E., et al., 2015). Recently, Anneken et al. reported a QTc shortening in women after administration of the selective estrogen receptor modulator clomiphene and the associated important estradiol release (Anneken, L., et al., 2016). Clomiphene, as a fertility inducer, exerts an antiestradiol effect on the pituitary axis. It inhibits IKr but does not prolong QTc in the guinea pig (Yuill, K.H., et al., 2004) making the results of Anneken et al. difficult to interpret.

Widely used oral contraceptives is another example of hormonal drugs potentially affecting QTC. Different types of synthetic progestins with different chemical structures, derived from nor-steroids or spironolactone, are currently used in the composition of contraceptive pills. In a cross-sectional study among 410,782 women, it was found that users of first and second generation progestins (derived from norsteroids) had a significantly shorter QTc than nonusers while users of fourth generation pills (derived from spironolactone) had a significantly longer QTc than nonusers (Sedlak, T., et al., 2013). Progesterone, the natural progestin, has been successfully used to reduce the incidence of spontaneous ventricular arrhythmias in a rabbit model of congenital type 2 LQTS (Odening, K.E., et al., 2012). In a prospective, double-blind, placebo-controlled, crossover study involving 15 healthy women, Tisdale et al. recently showed that use of $400 \mathrm{mg}$ oral progesterone once daily for 7 days during the follicular phase decreased ibutilide-induced QTc lengthening (Tisdale, J.E., et al., 2016). Pre-ibutilide QTc was significantly shorter during the progesterone phase ( $412 \pm 15$ vs. $419 \pm 14 \mathrm{msec} ; \mathrm{p}=0.04)$. Compared to placebo, maximal QTc $(443 \pm 17$ vs $458 \pm 19 \mathrm{msec} ; \mathrm{p}=0.003)$ and maximal percentage increase in QTc from pre-treatment value (7.5 \pm 2.4 vs $9.3 \pm 3.4 \% ; p=0.02)$ with ibutilide were less during the progesterone study period compared to the placebo period. Further investigations are needed to confirm if progesterone or other progestins can prevent or even treat drug-induced torsades de pointes by shortening QTc in humans, particularly in patients at risk such as those with congenital LQTS. 


\section{Implications for inclusion of women in thorough QT studies.}

Thorough QT studies form the regulatory cornerstone of cardiac proarrhythmic safety evaluation in drug development (International Conference on Harmonization - E14, 2005). QTc interval prolongation is used as a surrogate for a potential risk of proarrhythmia later in development. A positive signal (i.e. QT liability) is considered when the upper bound of the $95 \%$ one-sided confidence interval for the largest placebo-controlled, time-matched mean effect of the drug on the QTc interval is at least 10 ms compared to placebo. The variations of QTc interval duration linked to the menstrual cycle and sex hormones fluctuations in women (Figure 1) is generally ignored in thorough QT studies and can contribute to as much as 15 msec changes in QTc interval duration (Rodriguez, l., et al., 2001; Tisdale, J.E., et al., 2016), well above the threshold of regulatory concern. Investigators and regulatory agencies promoting the inclusion of women in thorough QT studies, or in its recently proposed alternative (Darpo, B., et al., 2015), should be aware of this source of variability particularly in protocols requiring several days of drug administration.

\section{Conclusion}

Women have been known for decades to have longer QTc and an increased risk of drug-induced torsades de pointes compared to men and this may in part be due to hormonal influences. Aldosterone prolongs QTc interval while mineralocorticoid receptor antagonists shorten ventricular repolarization. Endogenous and exogenous sex steroid hormones have variable influences on the duration of ventricular repolarization in both genders. Pathophysiological mechanisms underlying these findings are still imperfectly understood and nonclinical models have strong limitations due to the highly integrated nature of hormonal influences on QTc in humans. Testosterone in men and progesterone in women shorten repolarization while FSH prolongs repolarization in both genders. However, the interactions between these hormones and gonadotropin are complex. Several exogenous hormones carry a non-neutral effect on QTc, which remains to be unraveled. Finally, it should be acknowledged that the amplitude of these changes in the duration of ventricular repolarization are not necessarily 
associated with anti- or proarrhythmic consequences clinically. Also, investigators and regulatory agencies should be aware that, when women are included in a thorough QT study, the period of the menstrual cycle may significantly influence its results.

\section{Conflict of interest statement}

The authors declare that there are no conflicts of interest. 


\section{References}

Abehsira, G., Bachelot, A., Badilini, F., Koehl, L., Lebot, M., Favet, C., et al. (2016). Complex influence of gonadotropins and sex steroid hormones on QT interval duration. J Clin Endocrinol Metab, jc20161877 (in press).

Alexandre, J., Milliez, P., Rouet, R., Manrique, A., Allouche, S., Piccirillo, G., et al. (2015). Aldosterone and testosterone: two steroid hormones structurally related but with opposite electrophysiological properties during myocardial ischemia-reperfusion. Fundam Clin Pharmacol, 29, 341-351.

Alexandre, J., Puddu, P. E., Simard, C., Hof, T., Salle, L., Guinamard, R., et al. (2014). Proarrhythmic effects of aldosterone during myocardial ischemia-reperfusion: implication of the sarcolemmalKATP channels. J Cardiovasc Pharmacol, 64, 134-141.

Alexandre, J., Schiariti, M., Rouet, R., \& Puddu, P. E. (2013). Rabbit ventricular myocardium undergoing simulated ischemia and reperfusion in a double compartment tissue bath: a model to investigate both antiarrhythmic and arrhythmogenic likelihood. Int J Physiol Pathophysiol Pharmacol, 5, 5260.

Alizade, E., Avci, A., Fidan, S., Tabakci, M., Bulut, M., Zehir, R., et al. (2015). The Effect of Chronic Anabolic-Androgenic Steroid Use on Tp-E Interval, Tp-E/Qt Ratio, and Tp-E/Qtc Ratio in Male Bodybuilders. Ann Noninvasive Electrocardiol, 20, 592-600.

Anneken, L., Baumann, S., Vigneault, P., Biliczki, P., Friedrich, C., Xiao, L., et al. (2016). Estradiol regulates human QT-interval: acceleration of cardiac repolarization by enhanced $\mathrm{KCNH} 2$ membrane trafficking. Eur Heart J, 37, 640-650.

Arking, D. E., Pulit, S. L., Crotti, L., van der Harst, P., Munroe, P. B., Koopmann, T. T., et al. (2014). Genetic association study of QT interval highlights role for calcium signaling pathways in myocardial repolarization. Nat Genet, 46, 826-836.

Bai, C. X., Kurokawa, J., Tamagawa, M., Nakaya, H., \& Furukawa, T. (2005). Nontranscriptional regulation of cardiac repolarization currents by testosterone. Circulation, 112, 1701-1710.

Behr, E. R., Ritchie, M. D., Tanaka, T., Kaab, S., Crawford, D. C., Nicoletti, P., et al. (2013). Genome wide analysis of drug-induced torsades de pointes: lack of common variants with large effect sizes. PLoS One, 8, e78511.

Benitah, J. P., \& Vassort, G. (1999). Aldosterone upregulates $\mathrm{Ca}(2+)$ current in adult rat cardiomyocytes. Circ Res, 85, 1139-1145.

Bidoggia, H., Maciel, J. P., Capalozza, N., Mosca, S., Blaksley, E. J., Valverde, E., et al. (2000). Sex differences on the electrocardiographic pattern of cardiac repolarization: possible role of testosterone. Am Heart J, 140, 678-683.

Boyle, M. B., MacLusky, N. J., Naftolin, F., \& Kaczmarek, L. K. (1987). Hormonal regulation of K+-channel messenger RNA in rat myometrium during oestrus cycle and in pregnancy. Nature, 330, 373-375.

Burke, J. H., Ehlert, F. A., Kruse, J. T., Parker, M. A., Goldberger, J. J., \& Kadish, A. H. (1997). Genderspecific differences in the QT interval and the effect of autonomic tone and menstrual cycle in healthy adults. Am J Cardiol, 79, 178-181.

Caballero, R., Moreno, I., Gonzalez, T., Arias, C., Valenzuela, C., Delpon, E., et al. (2003). Spironolactone and its main metabolite, canrenoic acid, block human ether-a-go-go-related gene channels. Circulation, 107, 889-895.

Carnethon, M. R., Anthony, M. S., Cascio, W. E., Folsom, A. R., Rautaharju, P. M., Liao, D., et al. (2003). A prospective evaluation of the risk of QT prolongation with hormone replacement therapy: the atherosclerosis risk in communities study. Ann Epidemiol, 13, 530-536.

Chabbert Buffet, N., Djakoure, C., Maitre, S. C., \& Bouchard, P. (1998). Regulation of the human menstrual cycle. Front Neuroendocrinol, 19, 151-186.

Charbit, B., Christin-Maitre, S., Demolis, J. L., Soustre, E., Young, J., \& Funck-Brentano, C. (2009). Effects of testosterone on ventricular repolarization in hypogonadic men. Am J Cardiol, 103, 887-890. 
Chen, G., Yang, X., Alber, S., Shusterman, V., \& Salama, G. (2011). Regional genomic regulation of cardiac sodium-calcium exchanger by oestrogen. J Physiol, 589, 1061-1080.

Coker, S. J. (2008). Drugs for men and women - how important is gender as a risk factor for TdP? Pharmacol Ther, 119, 186-194.

Curtis, M. J., Hancox, J. C., Farkas, A., Wainwright, C. L., Stables, C. L., Saint, D. A., et al. (2013). The Lambeth Conventions (II): guidelines for the study of animal and human ventricular and supraventricular arrhythmias. Pharmacol Ther, 139, 213-248.

Darpo, B., Garnett, C., Keirns, J., \& Stockbridge, N. (2015). Implications of the IQ-CSRC Prospective Study: Time to Revise ICH E14. Drug Saf, 38, 773-780.

De Leo, V., la Marca, A., Agricola, E., Morgante, G., Mondillo, S., \& Setacci, C. (2000). Resting ECG is modified after oophorectomy and regresses with estrogen replacement therapy in premenopausal women. Maturitas, 36, 43-47.

Drici, M. D., Burklow, T. R., Haridasse, V., Glazer, R. I., \& Woosley, R. L. (1996). Sex hormones prolong the QT interval and downregulate potassium channel expression in the rabbit heart. Circulation, 94, 1471-1474.

Dritsas, A., Sbarouni, E., Gilligan, D., Nihoyannopoulos, P., \& Oakley, C. M. (1992). QT-interval abnormalities in hypertrophic cardiomyopathy. Clin Cardiol, 15, 739-742.

Endres, S., Mayuga, K. A., Cristofaro, A., Taneja, T., Goldberger, J. J., \& Kadish, A. H. (2004). Menstrual cycle and ST height. Ann Noninvasive Electrocardiol, 9, 121-126.

Etheridge, S. P., Compton, S. J., Tristani-Firouzi, M., \& Mason, J. W. (2003). A new oral therapy for long QT syndrome: long-term oral potassium improves repolarization in patients with HERG mutations. J Am Coll Cardiol, 42, 1777-1782.

Evans, R. M. (1988). The steroid and thyroid hormone receptor superfamily. Science, 240, 889-895.

Franz, M. R., Cima, R., Wang, D., Profitt, D., \& Kurz, R. (1992). Electrophysiological effects of myocardial stretch and mechanical determinants of stretch-activated arrhythmias. Circulation, 86, 968-978.

Funck-Brentano, C., \& Jaillon, P. (1993). Rate-corrected QT interval: techniques and limitations. Am J Cardiol, 72, 17B-22B.

Gazi, E., Gencer, M., Hanci, V., Temiz, A., Altun, B., Cakir Gungor, A. N., et al. (2013). Relationship of QT dispersion with sex hormones and insulin in young women with polycystic ovary syndrome: an observational study. Anadolu Kardiyol Derg, 13, 772-777.

available: $\quad$ http://www.genecards.org/cgibin/carddisp.pl?gene=FSHR\&keywords=FSHR (last checked: 10.07.2016).

Haseroth, K., Seyffart, K., Wehling, M., \& Christ, M. (2000). Effects of progestin-estrogen replacement therapy on QT-dispersion in postmenopausal women. Int J Cardiol, 75, 161-165; discussion 165166.

Hoffman, B. F., \& Suckling, E. E. (1956). Effect of several cations on transmembrane potentials of cardiac muscle. Am J Physiol, 186, 317-324.

Hu, C., Yan, C., Lin, J., Liu, S., \& Li, Y. (2011). Down-regulation of the human ether-a-go-go-related gene in rat cardiac hypertrophy. Am J Med Sci, 341, 119-125.

Hulot, J. S., Demolis, J. L., Riviere, R., Strabach, S., Christin-Maitre, S., \& Funck-Brentano, C. (2003). Influence of endogenous oestrogens on QT interval duration. Eur Heart J, 24, 1663-1667.

International Conference on Harmonization - E14. (2005). Clinical Evaluation of QT/QTc Interval Prolongation and Proarrhythmic Potential for Non-Antiarrhythmic Drugs; availability. Notice. Fed Regist, 70, 61134-61135 http://www.ich.org/products/guidelines/efficacy/efficacysingle/article/the-clinical-evaluation-of-qtqtc-interval-prolongation-and-proarrhythmicpotential-for-non-antiarrh.html (last checked: ).

Ishihara, K., Mitsuiye, T., Noma, A., \& Takano, M. (1989). The Mg2+ block and intrinsic gating underlying inward rectification of the K+ current in guinea-pig cardiac myocytes. J Physiol, 419, 297-320.

Jonsson, M. K., Vos, M. A., Duker, G., Demolombe, S., \& van Veen, T. A. (2010). Gender disparity in cardiac electrophysiology: implications for cardiac safety pharmacology. Pharmacol Ther, 127, 9-18. 
Jorgensen, I. N., Skakkebaek, A., Andersen, N. H., Pedersen, L. N., Hougaard, D. M., Bojesen, A., et al. (2015). Short QTc interval in males with klinefelter syndrome-influence of CAG repeat length, body composition, and testosterone replacement therapy. Pacing Clin Electrophysiol, 38, 472482.

Kadish, A. H., Greenland, P., Limacher, M. C., Frishman, W. H., Daugherty, S. A., \& Schwartz, J. B. (2004). Estrogen and progestin use and the QT interval in postmenopausal women. Ann Noninvasive Electrocardiol, 9, 366-374.

Kirilmaz, A., Bolu, E., Kilicaslan, F., Erinc, K., Uzun, M., Isik, E., et al. (2003). Comparison of electrocardiographic repolarization patterns between hypogonad males and normal subjects. Ann Noninvasive Electrocardiol, 8, 284-288.

Kurokawa, J., \& Furukawa, T. (2013). Non-genomic action of sex steroid hormones and cardiac repolarization. Biol Pharm Bull, 36, 8-12.

Kurokawa, J., Tamagawa, M., Harada, N., Honda, S., Bai, C. X., Nakaya, H., et al. (2008). Acute effects of oestrogen on the guinea pig and human $\mathrm{IKr}$ channels and drug-induced prolongation of cardiac repolarization. J Physiol, 586, 2961-2973.

Larsen, J. A., Tung, R. H., Sadananda, R., Goldberger, J. J., Horvath, G., Parker, M. A., et al. (1998). Effects of hormone replacement therapy on QT interval. Am J Cardiol, 82, 993-995.

Lawrence, C. L., Pollard, C. E., Hammond, T. G., \& Valentin, J. P. (2005). Nonclinical proarrhythmia models: predicting Torsades de Pointes. J Pharmacol Toxicol Methods, 52, 46-59.

Lee, T. M., Su, S. F., Lee, Y. T., \& Tsai, C. H. (1999). Effect of estrogen on ventricular repolarization in menopausal patients with syndrome $X$ and effects of nicorandil. Am J Cardiol, 84, 65-69.

Liu, X. K., Katchman, A., Whitfield, B. H., Wan, G., Janowski, E. M., Woosley, R. L., et al. (2003). In vivo androgen treatment shortens the QT interval and increases the densities of inward and delayed rectifier potassium currents in orchiectomized male rabbits. Cardiovasc Res, 57, 28-36.

Locati, E. H., Zareba, W., Moss, A. J., Schwartz, P. J., Vincent, G. M., Lehmann, M. H., et al. (1998). Ageand sex-related differences in clinical manifestations in patients with congenital long-QT syndrome: findings from the International LQTS Registry. Circulation, 97, 2237-2244.

Lussiana, C., Guani, B., Mari, C., Restagno, G., Massobrio, M., \& Revelli, A. (2008). Mutations and polymorphisms of the FSH receptor (FSHR) gene: clinical implications in female fecundity and molecular biology of FSHR protein and gene. Obstet Gynecol Surv, 63, 785-795.

Lv, Y., Bai, S., Zhang, H., Zhang, H., Meng, J., Li, L., et al. (2015). Aldosterone down-regulates the slowly activated delayed rectifier potassium current in adult guinea pig cardiomyocytes. Br J Pharmacol, 172, 5596-5608.

Mahesh, V. B. (1985). The dynamic interaction between steroids and gonadotropins in the mammalian ovulatory cycle. Neurosci Biobehav Rev, 9, 245-260.

Makkar, R. R., Fromm, B. S., Steinman, R. T., Meissner, M. D., \& Lehmann, M. H. (1993). Female gender as a risk factor for torsades de pointes associated with cardiovascular drugs. JAMA, 270, 25902597.

Malkin, C. J., Morris, P. D., Pugh, P. J., English, K. M., \& Channer, K. S. (2003). Effect of testosterone therapy on QT dispersion in men with heart failure. Am J Cardiol, 92, 1241-1243.

Martin, A. B., Garson, A., Jr., \& Perry, J. C. (1994). Prolonged QT interval in hypertrophic and dilated cardiomyopathy in children. Am Heart J, 127, 64-70.

Mason, J. W., Ramseth, D. J., Chanter, D. O., Moon, T. E., Goodman, D. B., \& Mendzelevski, B. (2007). Electrocardiographic reference ranges derived from 79,743 ambulatory subjects. J Electrocardiol, 40, 228-234.

Matsumura, K., Fujii, K., Kansui, Y., Arima, H., \& lida, M. (2005). Prolongation of the QT interval in primary aldosteronism. Clin Exp Pharmacol Physiol, 32, 66-69.

Maule, S., Bertello, C., Rabbia, F., Milan, A., Mulatero, P., Milazzo, V., et al. (2011). Ventricular repolarization before and after treatment in patients with secondary hypertension due to renalartery stenosis and primary aldosteronism. Hypertens Res, 34, 1078-1081. 
Maule, S., Mulatero, P., Milan, A., Leotta, G., Caserta, M., Bertello, C., et al. (2006). QT interval in patients with primary aldosteronism and low-renin essential hypertension. J Hypertens, 24, 2459-2464.

Milliez, P., Girerd, X., Plouin, P. F., Blacher, J., Safar, M. E., \& Mourad, J. J. (2005). Evidence for an increased rate of cardiovascular events in patients with primary aldosteronism. J Am Coll Cardiol, 45, 1243-1248.

Nakagawa, M., Ooie, T., Takahashi, N., Taniguchi, Y., Anan, F., Yonemochi, H., et al. (2006). Influence of menstrual cycle on QT interval dynamics. Pacing Clin Electrophysiol, 29, 607-613.

Nakamura, H., Kurokawa, J., Bai, C. X., Asada, K., Xu, J., Oren, R. V., et al. (2007). Progesterone regulates cardiac repolarization through a nongenomic pathway: an in vitro patch-clamp and computational modeling study. Circulation, 116, 2913-2922.

Norman, R. J., Dewailly, D., Legro, R. S., \& Hickey, T. E. (2007). Polycystic ovary syndrome. Lancet, 370, 685-697.

Nowinski, K., Pripp, U., Carlstrom, K., Landgren, B. M., Schenck-Gustafsson, K., \& Bergfeldt, L. (2002). Repolarization measures and their relation to sex hormones in postmenopausal women with cardiovascular disease receiving hormone replacement therapy. Am J Cardiol, 90, 1050-1055.

Odening, K. E., Choi, B. R., Liu, G. X., Hartmann, K., Ziv, O., Chaves, L., et al. (2012). Estradiol promotes sudden cardiac death in transgenic long QT type 2 rabbits while progesterone is protective. Heart Rhythm, 9, 823-832.

Ouvrard-Pascaud, A., Sainte-Marie, Y., Benitah, J. P., Perrier, R., Soukaseum, C., Nguyen Dinh Cat, A., et al. (2005). Conditional mineralocorticoid receptor expression in the heart leads to lifethreatening arrhythmias. Circulation, 111, 3025-3033.

Pecori Giraldi, F., Manzoni, G., Michailidis, J., Scacchi, M., Stramba-Badiale, M., \& Cavagnini, F. (2011). High prevalence of prolonged QT interval in obese hypogonadal males. Obesity (Silver Spring), 19, 2015-2018.

Pham, T. V., Sosunov, E. A., Gainullin, R. Z., Danilo, P., Jr., \& Rosen, M. R. (2001). Impact of sex and gonadal steroids on prolongation of ventricular repolarization and arrhythmias induced by I(K)blocking drugs. Circulation, 103, 2207-2212.

Philp, K. L., Hart, G., \& Coker, S. J. (2007). A gender-independent proarrhythmic action of 17betaestradiol in anaesthetized rabbits. Eur J Pharmacol, 575, 113-121.

Philp, K. L., Hussain, M., Byrne, N. F., Diver, M. J., Hart, G., \& Coker, S. J. (2006). Greater antiarrhythmic activity of acute 17 beta-estradiol in female than male anaesthetized rats: correlation with $\mathrm{Ca} 2+$ channel blockade. Br J Pharmacol, 149, 233-242.

Priori, S. G., Schwartz, P. J., Napolitano, C., Bloise, R., Ronchetti, E., Grillo, M., et al. (2003). Risk stratification in the long-QT syndrome. N Engl J Med, 348, 1866-1874.

Pugsley, M. K., Hancox, J. C., \& Curtis, M. J. (2008). Perception of validity of clinical and preclinical methods for assessment of torsades de pointes liability. Pharmacol Ther, 119, 115-117.

Rautaharju, P. M., Mason, J. W., \& Akiyama, T. (2014). New age- and sex-specific criteria for QT prolongation based on rate correction formulas that minimize bias at the upper normal limits. Int J Cardiol, 174, 535-540.

Ridley, J. M., Shuba, Y. M., James, A. F., \& Hancox, J. C. (2008). Modulation by testosterone of an endogenous hERG potassium channel current. J Physiol Pharmacol, 59, 395-407.

Roden, D. M. (2004). Drug-induced prolongation of the QT interval. N Engl J Med, 350, 1013-1022.

Rodriguez, I., Kilborn, M. J., Liu, X. K., Pezzullo, J. C., \& Woosley, R. L. (2001). Drug-induced QT prolongation in women during the menstrual cycle. JAMA, 285, 1322-1326.

Sağlam, H., Çakar, A., Köse, O., Kumsar, Ş., Budak, S., Gökhan Beyaz, S., et al. (2012). Changes in electrocardiogram findings during treatment with gonadotropin-releasing hormone agonist and surgical castration for prostate carcinoma. Open Journal of Urology, 2, 153-156 http://dx.doi.org/110.4236/oju.2012.223029.

Sauer, A. J., Moss, A. J., McNitt, S., Peterson, D. R., Zareba, W., Robinson, J. L., et al. (2007). Long QT syndrome in adults. J Am Coll Cardiol, 49, 329-337. 
Scragg, J. L., Jones, R. D., Channer, K. S., Jones, T. H., \& Peers, C. (2004). Testosterone is a potent inhibitor of L-type $\mathrm{Ca}(2+)$ channels. Biochem Biophys Res Commun, 318, 503-506.

Sedlak, T., Shufelt, C., Iribarren, C., Lyon, L. L., \& Bairey Merz, C. N. (2013). Oral contraceptive use and the ECG: evidence of an adverse QT effect on corrected QT interval. Ann Noninvasive Electrocardiol, 18, 389-398.

Seth, R., Moss, A. J., McNitt, S., Zareba, W., Andrews, M. L., Qi, M., et al. (2007). Long QT syndrome and pregnancy. J Am Coll Cardiol, 49, 1092-1098.

Shah, N. C., Pringle, S. D., Donnan, P. T., \& Struthers, A. D. (2007). Spironolactone has antiarrhythmic activity in ischaemic cardiac patients without cardiac failure. J Hypertens, 25, 2345-2351.

Sitruk-Ware, R. (2008). Pharmacological profile of progestins. Maturitas, 61, 151-157.

Stambler, B. S., Laurita, K. R., Shroff, S. C., Hoeker, G., \& Martovitz, N. L. (2009). Aldosterone blockade attenuates development of an electrophysiological substrate associated with ventricular tachyarrhythmias in heart failure. Heart Rhythm, 6, 776-783.

Thomsen, M. B., Matz, J., Volders, P. G., \& Vos, M. A. (2006). Assessing the proarrhythmic potential of drugs: current status of models and surrogate parameters of torsades de pointes arrhythmias. Pharmacol Ther, 112, 150-170.

Tillmann, H. C., Schumacher, B., Yasenyev, O., Junker, M., Christ, M., Feuring, M., et al. (2002). Acute effects of aldosterone on intracardiac monophasic action potentials. Int J Cardiol, 84, 33-39; discussion 39-40.

Tisdale, J. E., Jaynes, H. A., Kingery, J. R., Mourad, N. A., Trujillo, T. N., Overholser, B. R., et al. (2013). Development and validation of a risk score to predict QT interval prolongation in hospitalized patients. Circ Cardiovasc Qual Outcomes, 6, 479-487.

Tisdale, J. E., Jaynes, H. A., Overholser, B. R., Sowinski, K. M., Flockhart, D. A., \& Kovacs, R. J. (2016). Influence of Oral Progesterone Administration on Drug-Induced QT Interval Lengthening: A Randomized, Double-Blind, Placebo-Controlled Crossover Study JACC Clin Electrophysiol, doi: 10.1016/j.jacep.2016.1002.1015 (in press).

Tisdale, J. E., Overholser, B. R., Wroblewski, H. A., \& Sowinski, K. M. (2011). The influence of progesterone alone and in combination with estradiol on ventricular action potential duration and triangulation in response to potassium channel inhibition. J Cardiovasc Electrophysiol, 22, 325-331.

van Noord, C., Dorr, M., Sturkenboom, M. C., Straus, S. M., Reffelmann, T., Felix, S. B., et al. (2010). The association of serum testosterone levels and ventricular repolarization. Eur J Epidemiol, 25, 2128.

Vicente, J., Johannesen, L., Galeotti, L., \& Strauss, D. G. (2014). Mechanisms of sex and age differences in ventricular repolarization in humans. Am Heart J, 168, 749-756.

Vrtovec, B., Meden-Vrtovec, H., Jensterle, M., \& Radovancevic, B. (2008). Testosterone-related shortening of QTc interval in women with polycystic ovary syndrome. J Endocrinol Invest, 31, 653-655.

Vrtovec, B., Starc, V., \& Meden-Vrtovec, H. (2001). The effect of estrogen replacement therapy on ventricular repolarization dynamics in healthy postmenopausal women. J Electrocardiol, 34, 277283.

Wagner, M., Moritz, A., \& Volk, T. (2011). Interaction of gonadal steroids and the glucocorticoid corticosterone in the regulation of the L-type $\mathrm{Ca}(2+)$ current in rat left ventricular cardiomyocytes. Acta Physiol (Oxf), 202, 629-640.

White, C. M., Ferraro-Borgida, M. J., Moyna, N. M., McGill, C. C., Ahlberg, A. W., Thompson, P. D., et al. (1999). The effect of pharmacokinetically guided acute intravenous testosterone administration on electrocardiographic and blood pressure variables. J Clin Pharmacol, 39, 10381043.

Yan, G. X., Shimizu, W., \& Antzelevitch, C. (1998). Characteristics and distribution of M cells in arterially perfused canine left ventricular wedge preparations. Circulation, 98, 1921-1927.

Yang, P. C., \& Clancy, C. E. (2010). Effects of sex hormones on cardiac repolarization. J Cardiovasc Pharmacol, 56, 123-129. 
Yang, T., \& Roden, D. M. (1996). Extracellular potassium modulation of drug block of IKr. Implications for torsade de pointes and reverse use-dependence. Circulation, 93, 407-411.

Yap, Y. G., \& Camm, A. J. (2003). Drug induced QT prolongation and torsades de pointes. Heart, 89, 1363-1372.

Yee, K. M., Pringle, S. D., \& Struthers, A. D. (2001). Circadian variation in the effects of aldosterone blockade on heart rate variability and QT dispersion in congestive heart failure. J Am Coll Cardiol, 37, 1800-1807.

Yuill, K. H., Borg, J. J., Ridley, J. M., Milnes, J. T., Witchel, H. J., Paul, A. A., et al. (2004). Potent inhibition of human cardiac potassium (HERG) channels by the anti-estrogen agent clomiphene-without QT interval prolongation. Biochem Biophys Res Commun, 318, 556-561.

Zhang, Y., Ouyang, P., Post, W. S., Dalal, D., Vaidya, D., Blasco-Colmenares, E., et al. (2011). Sex-steroid hormones and electrocardiographic QT-interval duration: findings from the third National Health and Nutrition Examination Survey and the Multi-Ethnic Study of Atherosclerosis. Am J Epidemiol, 174, 403-411. 
Figure 1. Schematic representation of main sex hormone levels changes in plasma during the menstrual cycle in women of childbearing age and expected drug-induced QTc interval prolongation.

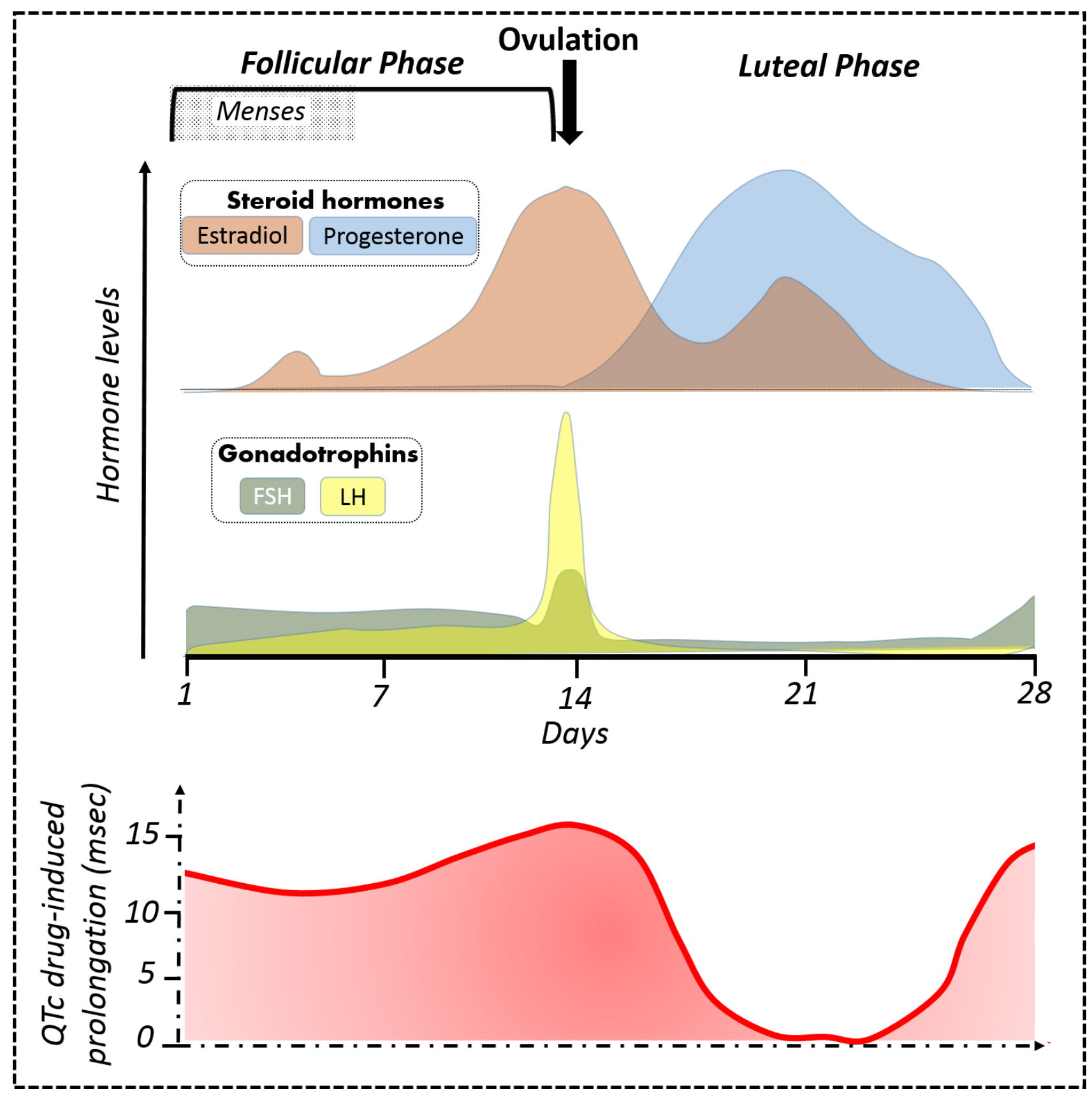


Figure 2. Influence of different steroid hormones on ionic currents, ventricular action potential and QTc interval duration: Progesterone (A), Estradiol (B), Testosterone (C) and Aldosterone (D)

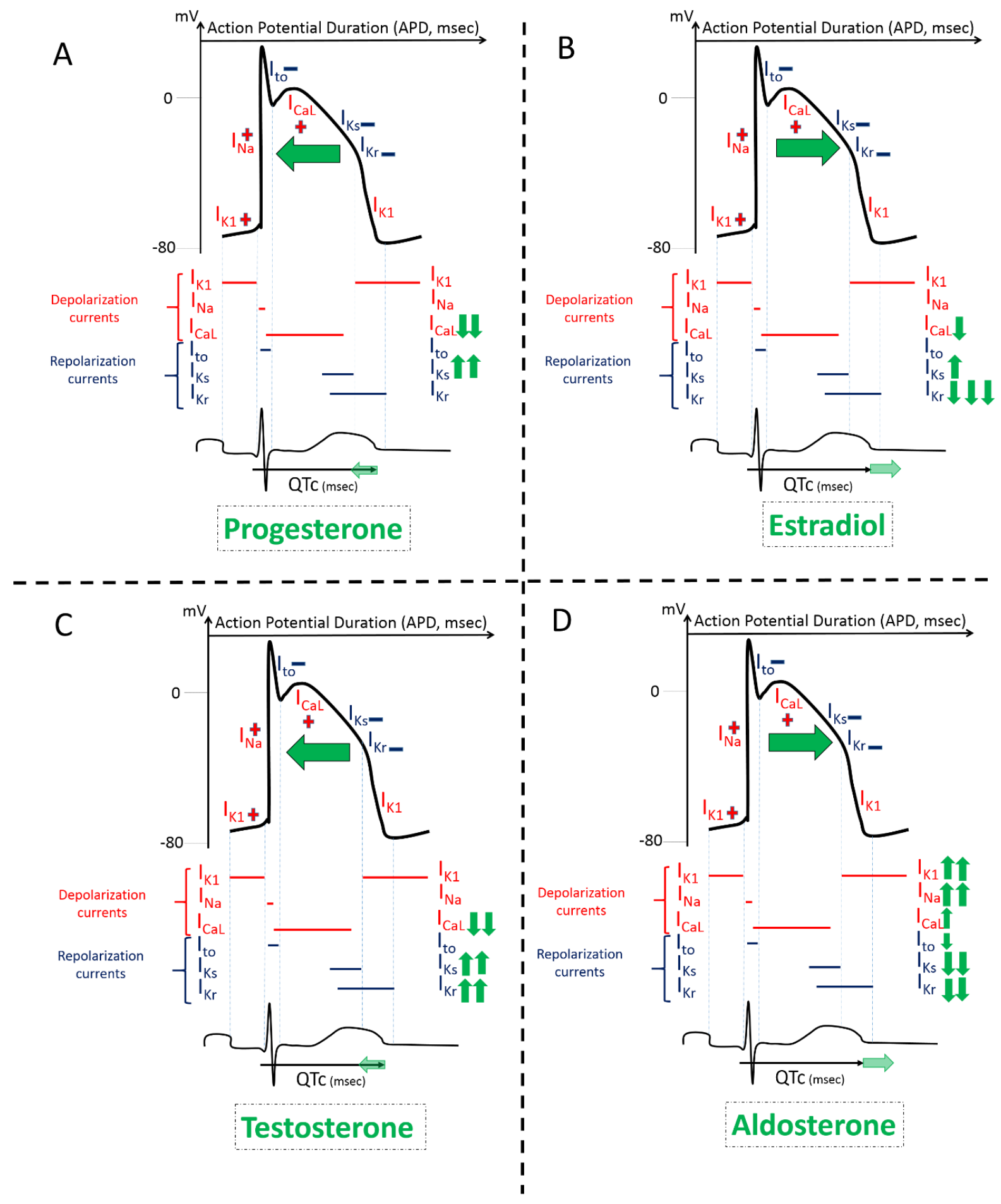


Table 1. Results of the main clinical studies evaluating the influence of estradiol on QTc interval duration in women

\begin{tabular}{|c|c|}
\hline Type of study - Population concerned & Main Results \\
\hline$>$ Estradiol: & \\
\hline $\begin{array}{l}\text { - Retrospective case-control study (Haseroth, K., et al., } 2000) \\
\text { - } 60 \text { postmenopausal women. Three groups: estrogen replacement therapy } \\
(n=16) \text {, progestin-estrogen replacement therapy }(n=22) \text { or control }(n=22)\end{array}$ & $\begin{array}{l}\text { - QTc increased in women under estrogen replacement therapy } \\
\text { compared to untreated controls and women under combined } \\
\text { progestin-estrogen therapy }\end{array}$ \\
\hline $\begin{array}{l}\text { - Prospective interventional study (De Leo, V., et al., 2000) } \\
\text { - } 26 \text { premenopausal and } 15 \text { postmenopausal women before and } 20-25 \text { days after } \\
\text { bilateral oophorectomy. } \\
\text { - Within the } 26 \text { premenopausal women oophorectomized; } 20-25 \text { days after the } \\
\text { procedure: } 14 \text { received transdermal estradiol, } 12 \text { did not receive any therapy. }\end{array}$ & $\begin{array}{l}\text { - In premenopausal women, T wave duration longer after oophorectomy } \\
(p<0.05) \\
\text { - In premenopausal women, T wave duration longer after oophorectomy } \\
\text { corrected by estradiol administration }(p<0.05)\end{array}$ \\
\hline $\begin{array}{l}\text { - Interventional randomized placebo-controlled study (Nowinski, K., et al., 2002) } \\
\text { - } 60 \text { postmenopausal women with cardiovascular diseases treated by oral estro- } \\
\text { progestative ( }: 20) \text {, transdermal estradiol with progestin ( } n: 20) \text {, or placebo } \\
(n=20)\end{array}$ & $\begin{array}{l}\text { - No change in QTc value under treatment ( } 6 \text { and } 12 \text { cycles) compared to } \\
\text { baseline in any group } \\
\text { - Inverse relation between QTc and log estradiol at baseline ( } r-0.43 \text {, } \\
p=0.006 \text { ) }\end{array}$ \\
\hline $\begin{array}{l}\text { - Prospective cohort study (Carnethon, M.R., et al., 2003) } \\
\text { - Women asked about hormonal replacement therapy used at } 4 \text { examinations } \\
\text { over } 9 \text { years : continuous estrogen therapy ( } n=455) \text {, continuous progestin- } \\
\text { estrogen therapy }(n=410) \text {, stopped }(n=161) \text { or never users }(n=2077)\end{array}$ & $\begin{array}{l}\text { - In women who used estrogen, QTc moderately but significantly } \\
\text { ( } p<0.01 \text { ) prolonged and risk of QT prolongation about twice that of } \\
\text { never users. }\end{array}$ \\
\hline $\begin{array}{l}\text { - Cross-sectional study (Kadish, A.H., et al., 2004) } \\
\text { - Women with past use of menopausal hormone therapy ( } \mathrm{n}=3891) \text { compared to } \\
\text { women never treated ( } \mathrm{n}=12451 \text { ) or currently taking unopposed estrogen } \\
\text { therapy ( } \mathrm{n}=9987) \text {, or currently taking estro-progestative therapy }(n=8049) \text {. }\end{array}$ & $\begin{array}{l}\text { - QTc in those never treated with menopausal hormone therapy shorter } \\
(423.1 \pm 0.2 \mathrm{~ms}) \text { compared to those currently on estrogen alone } \\
(425.6 \pm 0.2 \mathrm{~ms}, \mathrm{p}<0.05) \text { but not significantly different from the two } \\
\text { other groups. }\end{array}$ \\
\hline
\end{tabular}


- Interventional study (Lee, T.M., et al., 1999)

- 52 menopausal women with syndrome $X$ receiving estrogens as an acute intravenous combination of 10 different conjugated estrogens

- 20 control healthy menopausal women
- Maximal QTc increased from $448 \pm 30 \mathrm{~ms}$ to $469 \pm 30 \mathrm{~ms}$ at 20 minutes in women.

- No QTc change in controls

\section{Estradiol: studies not confirming an influence on QTc}

\begin{tabular}{|c|c|}
\hline $\begin{array}{l}\text { - Retrospective cross-sectional study (Larsen, J.A., et al., 1998) } \\
\text { - Postmenopausal women with estrogen alone group }(n=30) \text {, or combined estro- } \\
\text { progestative drugs }(n=44) \text { or without hormonal therapy }(n=132)\end{array}$ & - No difference in QTc between the three groups. \\
\hline $\begin{array}{l}\text { - Prospective interventional study (Rodriguez, I., et al., 2001) } \\
\text { - } 58 \text { healthy adults of whom } 20 \text { women ( } 38 \text { men) receiving ibutilide at } 3 \text { different } \\
\text { times: menstrual, follicular and luteal phases. }\end{array}$ & $\begin{array}{l}\text { - Estradiol }(r=0.14) \text { not correlated with ibutilide-induced QT } \\
\text { prolongation. }\end{array}$ \\
\hline $\begin{array}{l}\text { - Prospective interventional study (Vrtovec, B., et al., 2001) } \\
\text { - } 30 \text { postmenopausal women before and after } 10 \text { weeks of estrogen therapy } \\
\text { compared to } 12 \text { postmenopausal women with no estrogen }\end{array}$ & not change and was \\
\hline $\begin{array}{l}\text { - Prospective cohort study (Hulot, J.S., et al., 2003) } \\
\text { - } 21 \text { healthy women evaluated at } 2 \text { periods associated with a wide range of } \\
\text { estradiol levels: low (menses) and high (follicular phase). }\end{array}$ & $\begin{array}{l}\text { - No significant change in QTc observed within a large range of } \\
\text { physiological estradiol variations with constant progesterone levels } \\
\text { found during the menstrual cycle. } \\
\text { - No correlation found between estradiol levels and QTc }(p=0.92)\end{array}$ \\
\hline $\begin{array}{l}\text { - Prospective cohort study (Nakagawa, M., et al., 2006) } \\
\text { - } 11 \text { women evaluated at follicular and luteal phases and } 12 \text { men }\end{array}$ & $\begin{array}{l}\text { - In women, QT shorter in the luteal than in the follicular phase for all RR } \\
\text { intervals }(p<0.0001) \text {. } \\
\text { - Serum estradiol not different in the luteal and follicular phase in } \\
\text { women }\end{array}$ \\
\hline $\begin{array}{l}\text { - MESA Cross-sectional study (Zhang, Y., et al., 2011) } \\
\text { - } 1885 \text { postmenopausal women }\end{array}$ & $\begin{array}{l}\text { - Tendency to positive association between QTc and estradiol in } \\
\text { postmenopausal women }\end{array}$ \\
\hline
\end{tabular}

Abbreviations : $\mathrm{Cl}$, confidence interval ; IQ, interquartile range; $\mathrm{n}$, number of subjects; MESA, Multi-Ethnic Study of Atherosclerosis; ms, milliseconds; QTc, corrected QT interval duration; vs, versus 
Table 2. Results of the main clinical studies evaluating the influence of progesterone or testosterone on QTc interval duration in women

\section{Type of study - Population concerned}

Main Results

Progesterone: studies suggesting a shortening of QTc

\begin{tabular}{|c|c|}
\hline $\begin{array}{l}\text { - Prospective interventional study (Burke, J.H., et al., 1997) } \\
\text { - } 17 \text { women evaluated at } 3 \text { different times before and after double autonomic } \\
\text { blockade (atropine, propranolol) : at menstrual, follicular and luteal phases. }\end{array}$ & $\begin{array}{l}\text { - Following double autonomic blockade, QTc shorter }(p=0.05) \text { in women } \\
\text { in the luteal phase }(438 \pm 6 \mathrm{~ms}) \text { versus the menstrual }(446 \pm 15 \mathrm{~ms}) \text { or } \\
\text { the follicular phase ( } 444 \pm 13 \mathrm{~ms}) \text {. }\end{array}$ \\
\hline $\begin{array}{l}\text { - Retrospective case-control study (Haseroth, K., et al., } 2000) \\
\text { - } 60 \text { postmenopausal women. } 3 \text { groups: estrogen replacement therapy }(n=16) \text {, } \\
\text { progestin-estrogen replacement therapy }(n=22) \text {, or control }(n=22)\end{array}$ & $\begin{array}{l}\text { - QTc increased in women under estrogen replacement therapy } \\
\text { compared to untreated controls and to those under combined } \\
\text { progestin-estrogen therapy } \\
\text { - QTc not different between untreated controls and those under } \\
\text { combined therapy }\end{array}$ \\
\hline $\begin{array}{l}\text { - Prospective interventional study (Rodriguez, I., et al., 2001) } \\
\text { - } 58 \text { healthy adults including } 20 \text { women who received ibutilide at } 3 \text { different } \\
\text { times: menstrual, follicular and luteal phases. }\end{array}$ & $\begin{array}{l}\text { - QTc increase after Ibutilide greater for women during menses } \\
(63 \pm 13 \mathrm{~ms}) \text { and ovulatory phase }(59 \pm 17 \mathrm{~ms}) \text { compared with luteal } \\
\text { phase }(53 \pm 14 \mathrm{~ms}, \mathrm{p}<0.05) \text { and men }(46 \pm 6 \mathrm{~ms}, \mathrm{p}<0.05) \text {. } \\
\text { - Progesterone and progesterone/estradiol negatively correlated }(\mathrm{r}=-0.4) \\
\text { with drug-induced QT prolongation. }\end{array}$ \\
\hline $\begin{array}{l}\text { - Prospective cohort study (Carnethon, M.R., et al., } 2003) \\
\text { - Women asked about use of estrogen and progestin + estrogen replacement } \\
\text { therapy at } 4 \text { examinations over } 9 \text { years. Four groups: continuous estrogen } \\
\text { therapy ( } n=455) \text {, continuous progestin-estrogen therapy }(n=410) \text {, stopped } \\
\text { (n=161) or never used hormonal therapy }(n=2077)\end{array}$ & $\begin{array}{l}\text { - While QTC was moderately longer in women who used estrogen } \\
\text { compared with never users, this finding was not found in patients under } \\
\text { progestin-estrogen replacement therapy. }\end{array}$ \\
\hline
\end{tabular}




\begin{tabular}{|c|c|}
\hline $\begin{array}{l}\text { - Prospective interventional study (Endres, S., et al., 2004) } \\
\text { - } 22 \text { women evaluated at three different times before and after double } \\
\text { autonomic blockade (atropine and propranolol): menstrual, follicular and luteal } \\
\text { phases. }\end{array}$ & $\begin{array}{l}\text { - At baseline, QTc not significantly different among the } 3 \text { phases of the } \\
\text { menstrual cycle in women } \\
\text { - Following double autonomic blockade, QTc was shorter in women in } \\
\text { the luteal phase }(449 \pm 4 \mathrm{~ms}) \text { than during the menstrual }(455 \pm 6 \mathrm{~ms} \text {; } \\
p<0.05) \text { or the follicular phase }(476 \pm 10 \mathrm{~ms} ; p<0.01) \text {. }\end{array}$ \\
\hline $\begin{array}{l}\text { - Cross-sectional study (Kadish, A.H., et al., } 2004) \\
\text { - Women with past use of menopausal hormone therapy ( } n=3891) \text { compared to } \\
\text { women never treated ( } n=12451 \text { ) or currently taking unopposed estrogen } \\
\text { therapy ( } n=9987) \text {, or currently taking estro-progestative therapy }(n=8049) \text {. }\end{array}$ & $\begin{array}{l}\text { - QTc }=423.1 \pm 0.2 \mathrm{~ms} \text { in women never treated with menopausal hormone } \\
\text { therapy, } 423.9 \pm 0.3 \mathrm{~ms} \text { in past-menopausal hormone therapy users, } \\
424.0 \pm 0.2 \mathrm{~ms} \text { in women currently on combined estrogen- } \\
\text { progesterone therapy and } 425.6 \pm 0.2 \mathrm{~ms} \text { in those currently with } \\
\text { estrogen alone ( }<<0.05 \text { compared to never treated). }\end{array}$ \\
\hline $\begin{array}{l}\text { - Prospective cohort study (Nakagawa, M., et al., 2006) } \\
\text { - } 11 \text { women evaluated during the follicular and luteal phase }\end{array}$ & $\begin{array}{l}\text { - In women, QT shorter in the luteal than in the follicular phase } \\
(p<0.0001) \text { for all RR intervals. } \\
\text { - Serum progesterone higher during luteal vs. follicular phase in women. }\end{array}$ \\
\hline $\begin{array}{l}\text { - Prospective case-control study (Abehsira, G., et al., 2016) } \\
\text { - } 58 \text { patients with congenital adrenal hyperplasia patients and } 58 \text { age-matched } \\
\text { controls }\end{array}$ & $\begin{array}{l}\text { - Multivariable analysis in all women showed that } \\
\text { progesterone/estradiol ratio }(\beta=-0.33) \text { and FSH levels }(\beta=0.34) \text { were } \\
\text { related to QTc }(r=0.5, p<0.0001) \text { with no influence of disease status. }\end{array}$ \\
\hline $\begin{array}{l}\text { - Prospective, double-blind, interventional randomized crossover study with } \\
\text { ibutilide (Tisdale, J.E., et al., 2016) } \\
\text { - } 19 \text { women given } 7 \text { days of placebo or } 400 \mathrm{mg} \text { oral progesterone following } \\
\text { menses }\end{array}$ & $\begin{array}{l}\text { - Pre-ibutilide QTc significantly lower during the progesterone phase } \\
\text { ( } 412 \pm 15 \mathrm{~ms} \text { vs. } 419 \pm 14 \mathrm{~ms} ; \mathrm{p}=0.04) \text {. } \\
\text { - Maximal ibutilide-associated QTc ( } 443 \pm 17 \mathrm{~ms} \text { vs. } 458 \pm 19 \mathrm{~ms} ; \mathrm{p}=0.003 \text { ), } \\
\text { maximal percent increase in QTc from pre-treatment value }(7.5 \pm 2.4 \% \\
\text { vs. } 9.3 \% \pm 3.4 \% ; p=0.02 \text { ), and QTc area under the effect curve during } \\
\text { the first hour post-ibutilide administration ( } 497 \pm 13 \mathrm{~ms} \cdot \mathrm{h} \text { vs. } 510 \pm \\
16 \mathrm{~ms} \cdot \mathrm{h} ; \mathrm{p}=0.002 \text { ) smaller during the progesterone phase. }\end{array}$ \\
\hline
\end{tabular}




\section{Testosterone: studies suggesting a shortening of QTC}

\begin{tabular}{|l|l|l}
\hline - Prospective case-control study (Vrtovec, B., et al., 2008) & $\begin{array}{l}\text { QTc in PCOS patients shorter than in controls (401 } \pm \text { 61ms vs. } \\
467 \pm 61 \mathrm{~ms} ; \mathrm{p}=0.007), \\
\text { - } 119 \text { women with PCOS and } 64 \text { age-matched healthy control }\end{array}$ \\
\hline - Cross sectional study (Gazi, E., et al., 2013) & $\begin{array}{l}\text { Negative correlation ( } r-0.45, p=0.005) \text { between testosterone levels and } \\
\text { - } 25 \text { women patients }\end{array}$ \\
& $\begin{array}{l}\text { - QTc not different in the two groups } \\
\text { - Testosterone negatively correlated to QTc in PCOS patients ( } r-0.474,\end{array}$ \\
\hline
\end{tabular}

\section{Testosterone: studies not confirming an influence on QTC}

\begin{tabular}{|c|c|}
\hline $\begin{array}{l}\text { - Prospective interventional study (Rodriguez, I., et al., 2001) } \\
\text { - } 58 \text { adults of whom } 20 \text { women ( } 38 \text { men) received ibutilide on } 3 \text { different } \\
\text { occasions: menstrual, follicular and luteal phases. }\end{array}$ & $\begin{array}{l}\text { - Ibutilide-induced QTc increase not different in women during the luteal } \\
\text { phase ( } 53 \pm 14 \mathrm{~ms}) \text { compared with men }(46 \pm 16 \mathrm{~ms}) \text {. } \\
\text { - Testosterone ( } \mathrm{r}=0.09) \text {, not correlated with ibutilide-induced QTc } \\
\text { prolongation. }\end{array}$ \\
\hline $\begin{array}{l}\text { - Prospective cohort study (Nakagawa, M., et al., 2006) } \\
\text { - } 11 \text { women evaluated at follicular and luteal phases and } 12 \text { men }\end{array}$ & $\begin{array}{l}\text { - QT shorter for all RR intervals during the luteal than during the follicular } \\
\text { phase }(p<0.0001) \text {. } \\
\text { - Serum testosterone not different during the luteal and follicular phase. }\end{array}$ \\
\hline $\begin{array}{l}\text { - Cross-sectional studies (Zhang, Y., et al., 2011) } \\
\text { - } 1885 \text { postmenopausal women }\end{array}$ & - Serum testosterone not associated to QTc interval duration in women \\
\hline
\end{tabular}

Abbreviations: $\mathrm{n}$, number of subjects; ms, milliseconds; PCOS, polycystic ovary syndrome; QTc, corrected QT interval duration; vs., versus 
Table 3. Results of the main clinical studies evaluating influence of testosterone on QTc in men

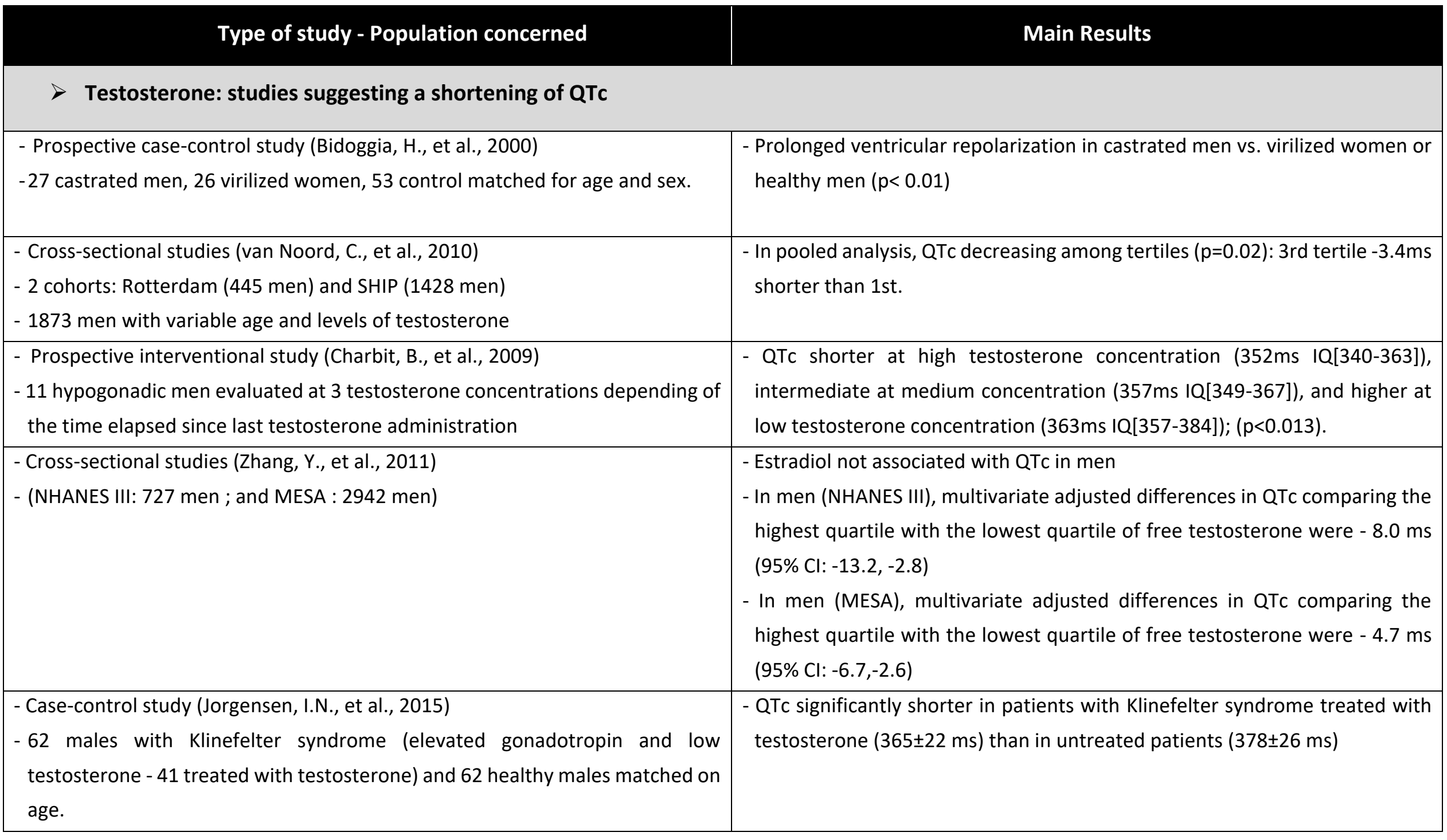




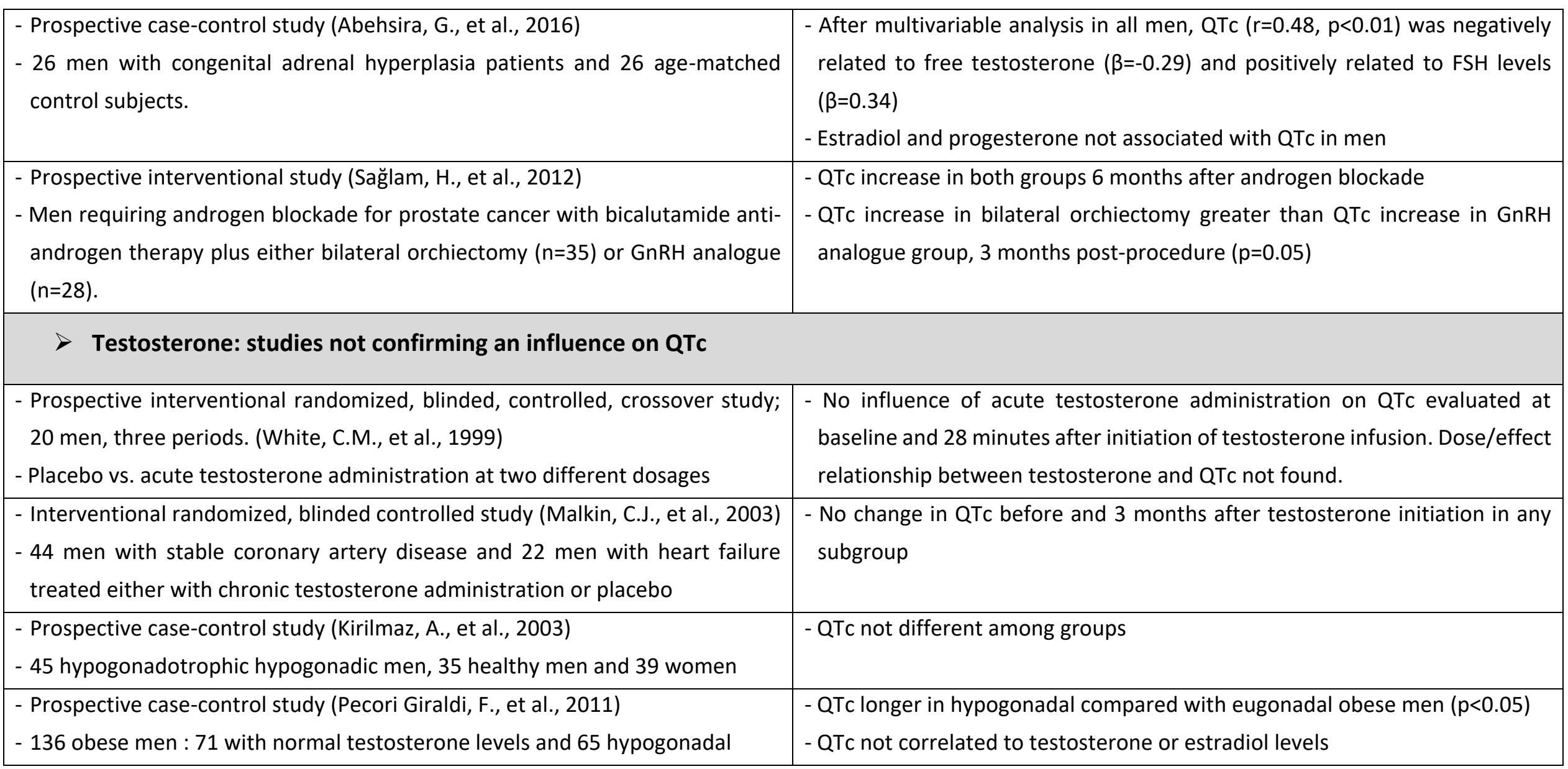

Abbreviations: $\mathrm{Cl}$, confidence interval; IQ, interquartile range; MESA, Multi-Ethnic Study of Atherosclerosis; ms, milliseconds; QTc, corrected QT interval duration; SHIP, Study of Health In Pomerania; vs., versus 
Table 4. Synthesis of the expected influence of endogenous and exogenous steroid hormones and gonadotrophins on QTC depending on gender

\begin{tabular}{|c|c|c|}
\hline Hormone & Men & Women \\
\hline Progesterone & - No influence within physiological ranges & - QTc shortening \\
\hline Estradiol & - No influence within physiological ranges & $\begin{array}{l}\text { - QTc lengthening (modest effect) particularly when } \\
\text { progesterone levels are low }\end{array}$ \\
\hline Testosterone & $\begin{array}{l}\text { - QTc shortening in normal men and in hypogonadic men } \\
\text { receiving testosterone } \\
\text { - QTc lengthening in case of peripheral hypogonadism } \\
\text { (very low testosterone levels) } \\
\text { - No additional effect on QTc in case of high supra } \\
\text { physiological levels: "plateau" effect. }\end{array}$ & $\begin{array}{l}\text { - None within physiological ranges } \\
\text { - QTc shortening in androgenized women with high supra } \\
\text { physiological testosterone levels }\end{array}$ \\
\hline Gonadotrophins (i.e. FSH) & - QTc lengthening & - QTc lengthening \\
\hline Aldosterone & - QTc lengthening & - QTc lengthening \\
\hline Exogenous steroids & $\begin{array}{l}\text { - QTc lengthening (some androgenic anabolic steroids) } \\
\text { - QTc lengthening (peripheral anti-androgens, e.g. } \\
\text { bicalutamide) } \\
\text { - QTc shortening (Mineralocorticoid Receptor Antagonists) }\end{array}$ & $\begin{array}{l}\text { - QTc lengthening (after clominophen) } \\
\text { - QTc shortening (progesterone and some progestins used } \\
\text { for replacement therapy, not all) } \\
\text { - Need for further investigation (contraceptive pills) } \\
\text { - QTc shortening (Mineralocorticoid Receptor Antagonists) }\end{array}$ \\
\hline
\end{tabular}

